\title{
Co-cultivation of Daphnia magna (Straus) and Desmodesmus armatus (chod.) Hegew. in recirculating aquaculture system wastewater
}

\author{
Larysa Cheban, Olga Grynko, Iryna Dorosh
}

Received - 17 May 2017/Accepted - 05 January 2018. Published online: 31 March 2018; Inland Fisheries Institute in Olsztyn, Poland Citation: Cheban L., Grynko O., Dorosh I. 2018 - Co-cultivation of Daphnia magna (Straus) and Desmodesmus armatus (chod.) Hegew. in recirculating aquaculture system wastewater - Fish. Aquat. Life 26: 57-64.

\begin{abstract}
The study focused on the development of co-cultivation schemes for Daphnia magna (Straus) and Desmodesmus armatus (Chod.) Hegew. Wastewater from a recirculating aquaculture system (RAS) was used as a medium for co-cultivation. Three schemes for D. magna and algae co-cultivation that differed in the timing of the introduction of Daphnia into the system were tested. Initially, D. armatus algae were cultivated to the exponential growth phase until cell numbers reached $5 \times 10^{4}$ cell $\times \mathrm{I}^{-1}$. This algal culture was introduced into the system for joint cultivation. D. magna was added immediately on the same day or three or six days after the algae. The number of $D$. magna individuals and the number of $D$. armatus cells were analyzed. It was established that the optimal scheme is the simultaneous introduction of algae and crustaceans into the cultivating system. By implementing this system it was possible to increase the number and biomass of $D$. magna by ten times in comparison to initial values.The biochemical composition of the D. magna obtained after co-cultivation and Daphnia that was fed traditionally once every $48 \mathrm{~h}$ with the same algae or yeast, Saccharomyces cerevisiae, was also compared. The scheme applied for D. magna and D. armatus simultaneous co-cultivation rendered it possible to obtain a biomass of Daphnia that was characterized by a protein content of $82.5 \%$ lipids of $6.7 \%$, and carotenoids of $15.3 \mathrm{mg} \times \mathrm{g}^{-1}$.
\end{abstract}

Keywords: Daphnia magna, Desmodesmus armatus, co-cultivation, feeding scheme, proteins, lipids, carotenoids

L. Cheban [ $\equiv]$, O. Grynko, I. Dorosh

Department of Biochemistry and Biotechnology

Yuriy Fedkovych Chernivtsi National University, Ukraine

e-mail: 1.cheban@chnu.edu.ua

\section{Introduction}

Mass production method of live food for young fish that have been developed in recent years permit switching to artificial fish cultivation on industrial scales in freshwater aquaculture. Natural food is a source of essential amino acids, unsaturated fatty acids, vitamins, minerals, and other components for fish that are necessary for growth throughout their life spans (Khudyi et al. 2014, Castro-Mejia et al. 2016). Fish growth rates and immunity and the assimilation of artificial feeds depends mainly on the share of natural food in diets. The artificial breeding of hydrobionts is one of the main ways of providing natural feeds for fish at different stages of their development. One of the limiting factors of the survival and the subsequent normal development of fish during periods of intense growth is the use of food that has a balanced nutritional composition (Lavens and Sorgeloos 1996, Ostroumova 2012). Increasing the efficiency of the use of live feeds as starter feeds for fish larvae is possible by developing technologies for optimizing the nutritional composition of such feeds. The nutritional value of a live food depends not only on the genetically determined properties of the 
species receiving the food, this can also be adjusted by the application of different types of food.

Daphnia magna (Straus) is cultivated on a mass scale in freshwater aquaculture, because young individuals are used as feed for fish larvae and mature individuals are the most valuable feed for young-of-the-year and older fish groups (Mychukova et al. 2007). Currently, there are two Daphnia cultivation methods. The first is the joint cultivation of crustaceans and the bacterio- and phytoplankton they feed on. The second is the separate cultivation of Daphnia and the organisms they feed on (Tuchapska and Krazhan 2014). The idea of using algae as feed for zooplankton is not new (Nandi and Sarma 2003, Brett et al. 2006). Algal biomass is easily digestible and accessible to zooplankton, and it provides them with all necessary nutrients (Becker 2007, Duong et al. 2015). Among all algal cultures, representatives of Chlorococcales algae are the most common feeds for zooplankton (Brown et al. 2002, Tuchapska and Krazhan 2014). However, Desmodesmus biomass can serve fully as an alternative feed for cultivating Cladocera crustaceans thanks to the small algal sizes and the sufficient content of amino acids, proteins, fatty acids, and carotenoids (Ahmed et al. 2014, Safafar et al. 2015, Villarruel-López et al. 2017). Depending on cultivation conditions, the algal biomass can contain 45 to $70 \%$ protein with a lipid range of 10 to 30\% (González López et al. 2010, Cheban et al. 2015). The profile and number of some fatty acids and amino acids can also be changed (Salama et al. 2013, Samek et al. 2013). This makes it possible to use microalgal biomasses as valuable sources of nutrients for zooplankton feeding (Macedo and Pinto-Coelho 2001, Castro-Mejia et al. 2016).

The main problem in zooplankton cultivation is the requirement of feeding it constantly. Most authors recommend regularly introducing small portions of algae into the cultivation system (Alva-Martinez et al. 2007, Castro-Mejia et al. 2016). This problem can be avoided by co-cultivating $D$. magna along with its feed. We attempted to develop a system of compatible cultivation in which both Daphnia and its algal feed are equally and simultaneously present. To accomplish this we had to select the appropriate algal species for cultivation and calculate the number of cells that should be introduced into the system. The choice of the nutrient medium that provides the needs of both zooplankton and algae for trace elements is also important. As we showed in a previous study, wastewater from RAS might be such a medium (Khudyi et al. 2016). Additionally, using alternative media in aquaculture can significantly reduce the costs of the final product (Arnold 2013).The purpose of this work was to develop a compatible cultivation scheme for D. magna (Straus) and Desmodesmus armatus (Chod.) Hegew. using wastewater from RAS as the culture medium and to estimate the nutrient value of Daphnia biomass cultivated under these conditions.

\section{Materials and methods}

The research was conducted on a pure algological culture of green alga, Desmodesmus armatus (Chod.) Hegew. (IBASH-A), obtained from the collection at the M.G. Kholodny Institute of Botany of the National Academy of Sciences of Ukraine. The initial culture of $D$. armatus was obtained by accumulatively culturing in wastewater from a RAS (Cheban et al. 2015). The monoculture of cladocerans D. magna (Straus) is the subject of research that is in the collection of the Institute of Biology, Chemistry, and Bioresourses of Yuriy Fedkovych Chernivtsi National University. Accumulative cultivation of the initial culture D. magna was conducted under conditions that were developed previously (Khudyi et al. 2016).

The wastewater from the RAS was removed from the mechanical filter, precipitated for 24-36 $\mathrm{h}$ at room temperature $\left(22 \pm 2^{\circ} \mathrm{C}\right)$ and poured into 450 $\mathrm{ml}$ jars for cultivation. We conducted the following manipulations to develop an optimal co-cultivation scheme. Initially, algae were cultivated separately to the exponential growth phase until the cell number reached $5 \times 10^{4}$ cell $\times \mathrm{l}^{-1}$, then $50 \mathrm{ml}$ of the algal culture was introduced into the system for joint cultivation. D. magna (25 ind. $\times 500 \mathrm{ml}^{-1}$ of the cultural medium) was added immediately on the same day or three or six days after the algae. 
Thus, three groups were formed:

1) with the simultaneous introduction of zooplankton and phytoplankton;

2) with the introduction of zooplankton three days after the phytoplankton;

3) with the introduction of zooplankton six days after the phytoplankton.

The co-cultivation of the organisms was conducted in a climatic chamber at a temperature of $21 \pm 2^{\circ} \mathrm{C}$ that was illuminated with 2500 lux fluorescent lamps for a 16-h photoperiod for 15 days. Throughout cultivation and in the final stages, the numbers of zooplankton individuals and phytoplankton cells were counted. The number of phytoplankton cells was calculated using a Fuchs-Rosenthal chamber, while the number of crustaceans was estimated using the aliquot method with a Bogorov camera under a MicroMed XS-3300 binocular microscope. At the next stage, when studying the biochemical composition of the D. magna biomass, we had two schemes in parallel with the previous three schemes. Here Daphnia organisms were cultivated separately from the algae, and they were fed once every two days either with the algae culture or yeast, $S$. cerevisiae, at the same concentrations of $5 \times 10^{4}$ cell $\times \mathrm{l}^{-1}$ (Kushniryk et al. 2015).

Sampling for biochemical analysis was conducted in the maximum productivity phase. Concentrated samples of phytoplankton and zooplankton were treated with a USDN-2T ultrasonic disintegrator. The test material was homogenized at $+4^{\circ} \mathrm{C}$ using phosphate buffer $\mathrm{pH}$ 7.4. The homogenate was centrifuged at $1500 \mathrm{~g}$ for $15 \mathrm{~min}$ in a Biofuge Stratos (Heraeus Instruments). The content of the main nutrients was designated in these samples. Total lipids extracted with the Folch method (Folch et al. 1957) were determined after the samples were subjected to acid hydrolysis and the subsequent reaction between decomposition products and phospho-vanillin reagent (Knight et al. 1972). Total protein content was determined with the Lowry method (Lowry et al. 1951). Carbohydrate content was determined with color reaction with a anthrone reagent (Roe 1955). Carotenoid extraction from the zooplankton biomass was conducted with acetone after treatment with
USDN-2T ultrasonic disintegrator, and this was analysed spectrophotometrically at the optimum wavelength (Tanaka 1978, Sánchez-Macías et al. 2008). All calculations were performed on dry weights. To determine humidity and dry weights, previously weighed samples were dried at $60^{\circ} \mathrm{C}$ for $24 \mathrm{~h}$ to a constant mass (Harris et al. 2000).

\section{Results}

After D. armatus reached the exponential growth phase, the algae were added to the system for co-cultivation at a concentration of at least $5 \times 10^{4}$ cell $\times \mathrm{l}^{-1}$. D. magna organisms were added to the cultivation jars simultaneously or three or six days after the algae. It was noted that the phytoplankton grew better when Daphnia was introduced into the cultivation system later (Fig. 1). When zooplankton was introduced six days after the phytoplankton, a gradual increase in the cells number of the $D$. armatus culture was observed, which was similar to cumulative cultivation. The same dependence was noted after the introduction of zooplankton three days after D. armatus. The number of algal cells decreased rapidly the day after the addition of Daphnia. When the phytoplankton and zooplankton were introduced simultaneously, the number of $D$. armatus cells in the culture gradually increased until mid-cultivation, although it did not reach the number of cells that was detected in the previous two cases. At each of the designated stages the number of microalgae cells did not exceed $7 \times 10^{4}$ cell $\times 1^{-1}$.

Consequently, the culture of microalgae was characterized by sufficiently constant indicators of growth rate and cell numbers in all of the schemes proposed. The zooplankton grew better with the simultaneous introduction of phytoplankton and zooplankton into the culture medium (Fig. 1). The microalgae growth rate under these conditions was low, and the microalgae did not inhibit zooplankton development. The number of D. magna individuals increased proportionally throughout the cultivation period and reached about 260 ind. $\times \mathrm{l}^{-1}$ in the final 

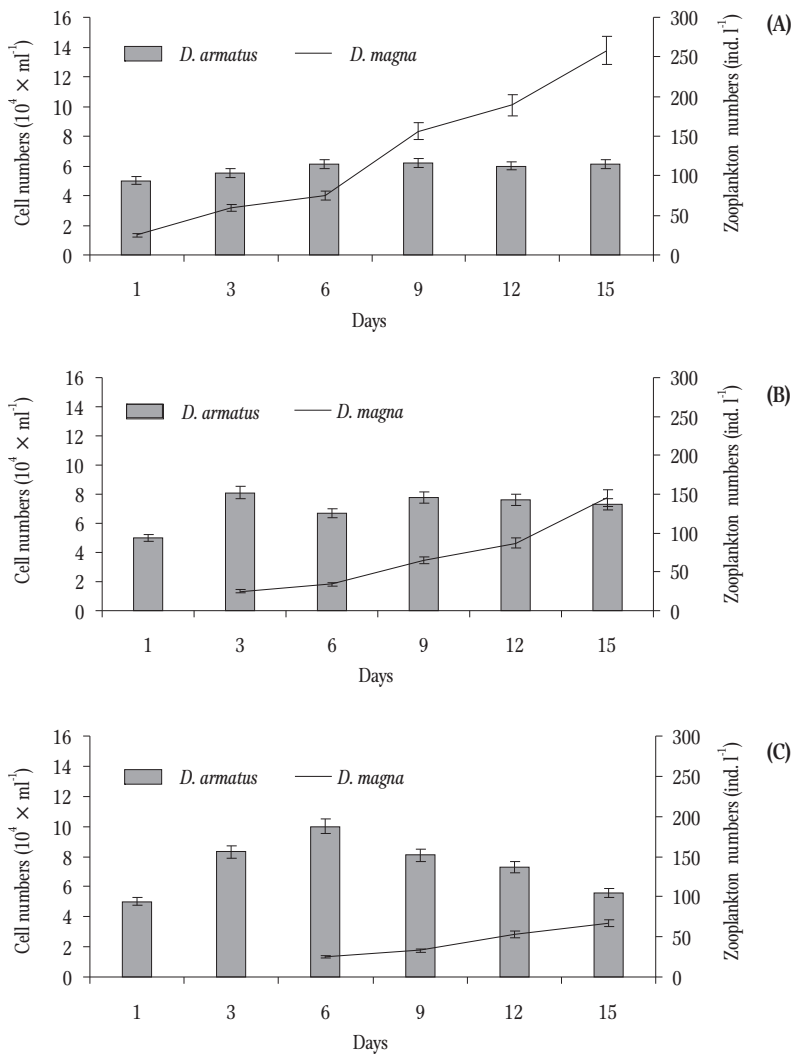

Figure 1. Changes in D. armatus cell numbers and D. magna individuals during different co-cultivation schemes. A - Simultaneous introduction of zooplankton and phytoplankton, B Introduction of zooplankton three days after phytoplankton, C Introduction of zooplankton six days after phytoplankton.

stage. When the zooplankton was added to the culture after the microalgae, the number of D. magna individuals increased slowly and was two to three times lower on measurement days than when both components of the system were introduced simultaneously.

Thus, after the introduction of zooplankton, in six days the growth phytoplankton growth was more intense than that of D. magna. The slowest growth of zooplankton was observed with this method of co-cultivation. On day 15 it numbered 67 ind. $\times \mathrm{l}^{-1}$, which was 2.5 times less than when zooplankton was introduced on day three, and four times less than when introduction was simultaneous. Since on day 15 the number of $D$. magna individuals cultivated was still high enough for all the schemes applied, we conducted further co-cultivation of the species studied. However, from days 17-20 the growth rate of algal biomass gradually decreased, which inevitably led to reduced numbers of D. magna individuals. Using the number of Daphnia individuals in the cultivation system and their average size, we calculated indicators of zooplankton biomass accumulation in the final phase of cultivation (Table 1). This indicated that after zooplankton introduction to the cultivation system on day six, the number of Daphnia individuals was much smaller but they were larger. The indicator of zooplankton biomass accumulation was only 1.3 times lower compared to the second co-cultivation scheme, although the number of Daphnia individuals under these two schemes differed by 2.2 times.

The content of major nutrients in Daphnia, grown under co-cultivation, and zooplankton, fed on $S$. cerevisiae or D. armatus once every $48 \mathrm{~h}$, was compared (Fig. 2). The Daphnia biomass fed on yeast was

Table 1

Indicators of Daphnia magna biomass accumulation during co-cultivation with food (mean \pm SD)

\begin{tabular}{|c|c|c|c|c|c|}
\hline Indicators & Yeast food & Algal food & $\begin{array}{l}\text { Simultaneous in- } \\
\text { troduction of zoo- } \\
\text { plankton and } \\
\text { phytoplankton }\end{array}$ & $\begin{array}{l}\text { Zooplankton } \\
\text { introduced } \\
\text { on day } 3\end{array}$ & $\begin{array}{l}\text { Zooplankton } \\
\text { introduced } \\
\text { on day } 6\end{array}$ \\
\hline Number of individuals (ind. $\times \mathrm{l}^{-1}$ ) & $245 \pm 14.5^{\mathrm{a}}$ & $253 \pm 13.8^{\mathrm{a}}$ & $258 \pm 12.3^{\mathrm{a}}$ & $145 \pm 7.6^{\mathrm{b}}$ & $67 \pm 2.4^{\mathrm{c}}$ \\
\hline Average body length (mm) & $1.3-1.5$ & $1.3-1.5$ & $1.3-1.5$ & $1.3-1.5$ & $1.5-1.7$ \\
\hline Average weight of Daphnia (mg) & $0.18 \pm 0.007^{\mathrm{a}}$ & $0.18 \pm 0.01^{\mathrm{a}}$ & $0.18 \pm 0.008^{\mathrm{a}}$ & $0.18 \pm 0.006^{\mathrm{a}}$ & $0.29 \pm 0.011^{b}$ \\
\hline Biomass accumulation by the culture $\left(\mathrm{mg} \times \mathrm{l}^{-1}\right)$ & $44.1 \pm 3.11^{\mathrm{a}}$ & $45.5 \pm 2.02^{\mathrm{a}}$ & $46.5 \pm 2.98^{\mathrm{a}}$ & $26.2 \pm 1.27^{\mathrm{b}}$ & $19.4 \pm 0.85^{\mathrm{c}}$ \\
\hline
\end{tabular}

Values with different superscript letters are significantly different $(\mathrm{P}<0.05)$ 

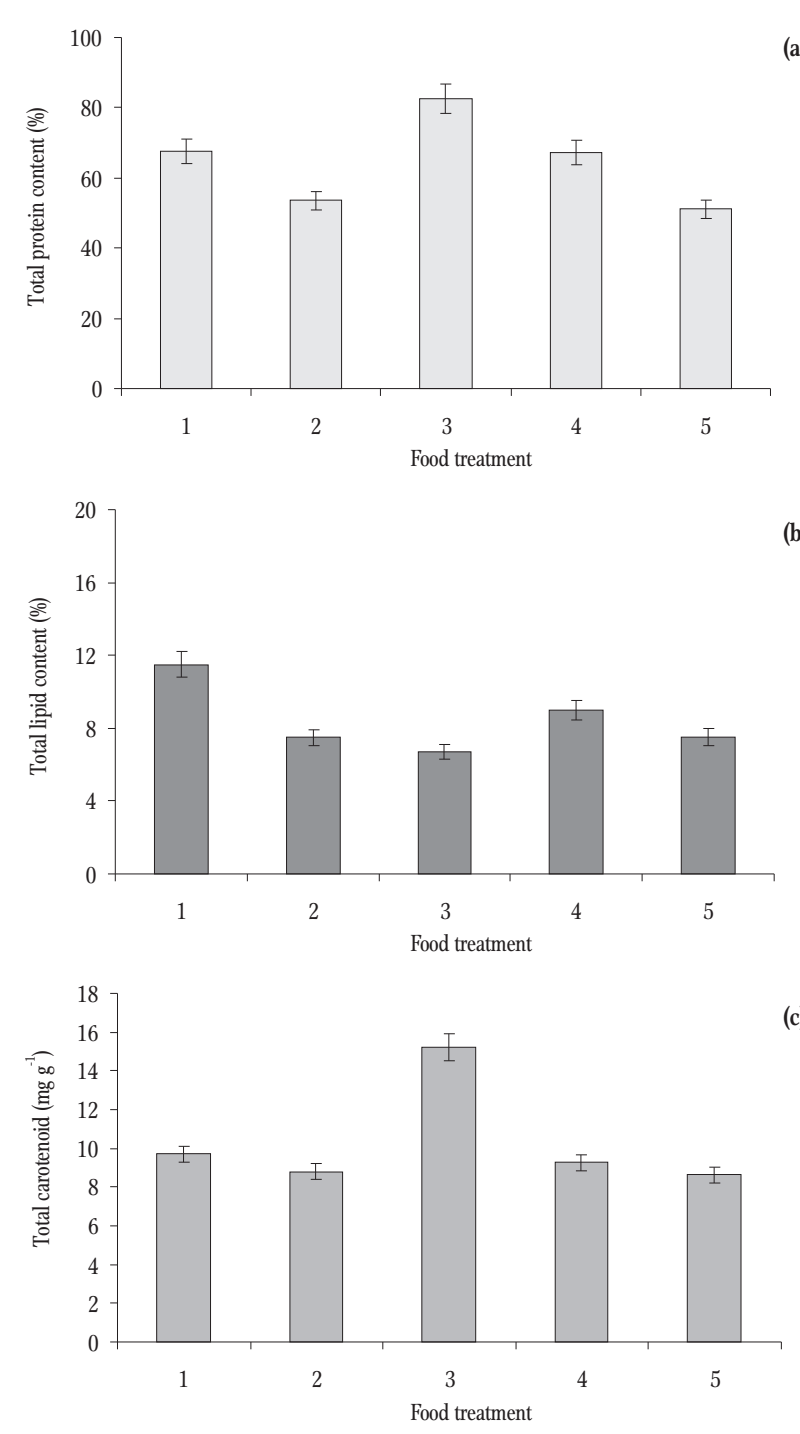

Figure 2. Mean protein (a), lipid (b) and carotenoid (c) contents of Daphnia magna cultivated under different nutrient treatments. 1 - Daphnia fed yeast; 2 - Daphnia fed algae; 3 - simultaneous introduction of Daphnia and phytoplankton; 4 - Daphnia introduced three days after phytoplankton, 5 - Daphnia introduction six days after phytoplankton.

characterized by a total protein content of $67.6 \%$. When Daphnia was co-cultivated with alternative food (D. armatus), the total protein content was 82.5\%, which was 1.2 times higher than that obtained with the yeast diet and 1.5 times higher than that with the regular D. armatus diet. The lipid analysis of the D. magna biomass indicated some other regularities. The highest lipid content $(11.5 \%)$ was noted in the zooplankton biomass grown on yeast.
When the phytoplankton and zooplankton were introduced simultaneously, the lipid content in the Daphnia biomass was $6.7 \%$, while that in the zooplankton fed algae was $7.5 \%$. The highest carotenoid content $\left(15.24 \mathrm{mg} \times \mathrm{g}^{-1}\right)$ was noted in the zooplankton biomass cultured with D. armatus. Almost the same level of carotenoid accumulation was observed in Daphnia biomass fed on yeast and microalgae at $9.7 \mathrm{mg} \times \mathrm{g}^{-1}$ and $8.8 \mathrm{mg} \times \mathrm{g}^{-1}$ dry weight, respectively.

Hence, according to the research results, we recommend the scheme of D. magna and D. armatus co-cultivation with the simultaneous introduction of zooplankton and phytoplankton to the cultivation system at an initial ratio of $5 \times 10^{4}$ cell $\times 1^{-1}$ per 25 Daphnia individuals.

\section{Discussion}

The efficiency of growing any heterotrophic organism will depend primarily on the nutritional value of the food supplied. Traditionally, yeast, Saccharomyces cerevisiae, is used as the food for cultivating planktonic crustaceans, and it is also used frequently as a starter feed for fish larvae (Chakri 2014). Although yeast is used by Daphnia as food, it serves primarily as an organic fertilizer for the development of bacteria and algae (Khatun et al. 2014). Feeding zooplankton algae, the introduction of which in the diet of hydrobionts significantly affects the growth of crustacean biomass, is an alternative to yeast (Moyseev 2007, Khatun et al. 2014). The total protein content in algal biomass depends on systematic features, and the protein content can range from 30 to $55 \%$ of dry weight when the culture transitions to a stationary state (González López et al. 2010, Kim and Wijesekara 2010). Algae can also produce different types of lipids, such as glycolipids, phospholipids (polar lipids), and glycerolipids. They also have large reserves of neutral lipids and free fatty acids, and the lipid content of microalgae ranges from 10 to $50 \%$. The lipid content and the number or location of double bonds in fatty acids also vary depending on the 
species of algae and the conditions of their cultivation (Hu et al. 2008). The value of algae as food is also increased because they contain carotenoid, xanthophyll, and chlorophyll pigments. In general, the carotenoid and chlorophyll content in algae is higher than in other plants. Additionally, they contain other valuable antioxidants, such as $0.01-3 \%$ tocopherols (vitamin E), $0.1-1.5 \%$ ascorbic acid (vitamin C), and phenolic compounds (Mulders et al. 2013, Koller et al. 2014).

Food availability is a major factor in the dynamics of the growth and density of planktonic crustaceans, and, hence, their productivity. Food provisions define how fully a crustacean population is able to realize its reproductive potential. The lack of food supply not only results in limited fertility, but it can also sometimes be a mortality factor (Castro-Mejia et al. 2016). Insufficient amounts of food is a direct cause of crustacean death, especially in the early stages of development. To avoid having to constantly feed crustaceans, we tried to develop a scheme of co-cultivation. The management this study required taking many factors into account, including the optimal composition of the culture medium. The medium selected had to meet all the requirements of both the algae and the crustaceans.

The possibility of cultivating the two species investigated in this study in RAS wastewater was demonstrated previously (Khudyi et al. 2016). It was established that the use of RAS wastewater for crustacean cultivation not only delays the slowing of culture growth, but it also leads to increased zooplankton number and biomass. This medium is a valuable source of all the elements required by algae that permits producing an actively growing productive culture (Cheban et al. 2015). It is important to consider the size of both cultivated species when cultivating phytoplankton and zooplankton together. Many algae cannot be used as feed for Cladocera because they interfere with normal filtration processes, which reduces the consumption rate of available small food items (Castro-Mejia et al. 2016).

The Chlorococcales algal culture $D$. armatus is characterized by a small size and a high content of basic nutrients, which means it is appropriate for use as food for zooplankton. There are several schemes for introducing Cladocera crustaceans and feed organisms into the culture medium. The initial culture of $D$. magna can be introduced on the same day or within one to two days when the number of bacterial and algal cells increases significantly. Otherwise, the Daphnia culture is fed regularly for a prescribed period of time with a quantity of about $10 \mathrm{~g} \times \mathrm{m}^{3}$ yeast (Tuchapska and Krazhan 2014).

The sequence in which the two cultivated species are introduced is also important, and the amount and availability of food for the zooplankton determines its productivity. Three co-cultivation schemes were tested in which the timing of the zooplankton introduction to the cultivation system differed. After the Daphnia were introduced into the system, they adapted quickly enough and actively consumed the available algae. Delaying the introduction of the Daphnia culture into the co-cultivation system led to an intense increase in D. armatus biomass. However, the number of Daphnia individuals was lower in comparison to that recorded after simultaneous introduction. As was noted, the Daphnia culture reproduced more slowly than when it was introduced to the cultivation system later. Obviously, the intense development of algae inhibited zooplankton growth. No explanation of this was found in the available literature, but most likely it was caused by qualitative changes of the cultivation medium and the massive accumulation of algal biomass. The highest number of $D$. magna individuals was obtained when the zooplankton and phytoplankton were introduced simultaneously into the cultivation system. Apparently, this was explained by the constant availability of Daphnia food under the conditions of co-cultivation with the microalgae. During co-cultivation, the duration of $D$. armatus growth decreased in comparison with the monoculture growth period (from 40 to 15 days) (Cheban et al. 2015) because of the gradual consumption of the culture by the Daphnia, which exhausted the nutrient medium and the accumulation of cladoceran metabolites and algal exometabolites in the culture medium.

Another important factor when using zooplankton as food for fish is the nutritional value of $D$. magna. 
For example, Daphnia was used to feed juvenile Cyprinus carpio L. (Bogut et al. 2010, Suantika et al. 2016). It was shown that the protein content and amino acid composition of Daphnia biomass meets the protein requirements not only of juveniles carp but also those of older age groups. Cladocera crustaceans can accumulate large quantities of protein and lipid in their biomass, but these amounts depend on the diet (Macedo and Pinto-Coelho 2001). It is known that protein content can range from 45 to $70 \%$, while that of lipid can range from 11 to $27 \%$ depending on their content in food and the physiological characteristics of the organisms (Ricardi and Mangoni 1999).

The biochemical characteristics of Daphnia obtained through co-cultivation using a regular diet of yeast or algae were compared. The highest protein and carotenoid contents in the D. magna biomass were noted when they were co-cultivated with D. armatus. The lipid content in the Daphnia biomass was slightly lower when they were co-cultivated. The reason for this difference could have been the low lipid content in the $D$. armatus biomass from the original culture, which, in turn, affected lipid accumulation in the zooplankton biomass. A positive result of the scheme applied to co-cultivate Daphnia with its food was the sufficiently high carotenoid content. Crustaceans, as in all animals, cannot synthesize carotenoids, therefore these substances must be delivered by foraging on organisms capable of carotenogenesis (algae, yeast, etc.) (Tanaka 1978, Guedes et al. 2011). Using D. armatus microalgae as a source of carotenoids permitted increasing the carotenoid content in the Daphnia biomass to $15.24 \mathrm{mg} \times \mathrm{g}^{-1}$.

\section{Conclusions}

This study demonstrates that it is possible to co-cultivate $D$. magna with $D$. armatus. The most effective scheme was to introduce the phytoplankton and zooplankton simultaneously to the culture medium. Under these conditions it was possible to grow the largest number of Daphnia individuals and to maintain optimal growth rates for both the phytoplankton and zooplankton throughout the co-cultivation period. During the joint cultivation of $D$. magna and D. armatus it was possible to avoid the problem of the zooplankton continuously feeding on food and to obtain a Daphnia biomass with a sufficiently high content of total proteins, lipids, and carotenoids.

Author contributions. L.C., O.G., and I.D. conceived of and implemented the experiment; I.D and O.G. performed the experiment; L.C. analyzed the data and wrote the paper.

\section{References}

Ahmed F., Fanning K., Netzel M., Turner W., Li Y., Schenk P.M. 2014 - Profiling of carotenoids and antioxidant capacity of microalgae from subtropical coastal and brackish waters - Food Chem. 165: 300-306.

Alva-Martinez A.F., Sarma S.S.S., Nandini S. 2007 - Effect of mixed diets (cyanobacteria and green algae) on the population growth of the cladocerans Ceriodaphnia dubia and Moina macrocopa. - Aquat. Ecol. 41: 579-585.

Arnold M. 2013 - Sustainable algal biomass products by cultivation in wastewater flows - VTT Technical Research Center, Espoo.

Becker E.W. 2007 - Micro-algae as a source of protein Biotechnol. Adv. 25: 207-210.

Bogut I., Adamek Z., Pukadija Z., Galovi D. 2010 - Nutritional value of planktonic Cladocera Daphnia magna for common carp (Cyprinus carpio) fry feeding - Croat. J. Fish. 68: $1-10$.

Brett M.T., Müller-Navarra D.C., Ballantyne A.P., Ravet J.L., Goldman C.R. 2006 - Daphnia fatty acid composition reflects that of their diet-Limnol. Oceanogr. 51: 2428-2437.

Brown M.R. 2002 - Nutritional value of microalgae for aquculture - In: Avances en Nutrición Acuícola VI. Memorias del VI Simposium Internacional de Nutrición Acuícola (Eds) L.E. Cruz-Suárez D., Ricque-Marie M., Tapia-Salazar M.G., Gaxiola-Cortés N. Simoes, 3 al 6 de Septiembre del 2002. Cancún, Quintana Roo, México.

Castro-Mejia J., Ocampo-Cervantes J.A., Castro-Mejia G., Cruz-Cruz I., Monroy-Dosta M. del C., Becerril-Cortes D. 2016 - Laboratory production of Daphnia magna (Straus, 1820) fed with microalgae and active dry yeast J. Entomol. Zool. St. 4: 548-553.

Chakri K., Berrak H., Samraoui B. 2014 - Effect of food concentration on the development, growth, reproduction and total life span of Simocephalus expinosus Koch (Cladocera: Daphniidae) - Ann. Biol. Res. 5: 55-58.

Cheban L., Malischuk I., Marchenko M. 2015 - Peculiarities of cultivation Desmodedesmus armatus (Chocl.) Hegew. in the wash water from RAS - Arch. Pol. Fish. 23: 155-162. 
Duong V.T., Ahmed F., Thomas-Hall S.R., Quigley S., Nowak E., Schenk P.M. 2015 - High protein- and high lipid-producing microalgae from Northern Australia as potential feedstock for animal feed and biodiesel - Front. Bioeng. Biotechnol. 3: 53-61.

Folch J., Lees M., Stanley G.H.S. 1957 - A simple method for the isolation and purification of total lipids from animal tissues - J. Biol. Chem. 226: 497-509.

González López C.V., García M.C.C., Fernández F.G.A., Bustos C.S., Chisti Y., Sevilla J.M.F. 2010 - Protein measurements of microalgal and cyanobacterial biomass Bioresour. Technol. 101: 7587-7591.

Guedes A.C., Amaro H.M., Malcata F.X. 2011 - Microalgae as sources of carotenoids - Mar. Drugs 9: 625-644.

Harris R.P., Wiebe P.H., Lenz J., Skjoldal H.R., Huntley M. 2000 - ICES Zooplankton methodology manual - Academic Press, London.

Hu Q., Sommerfeld M., Jarvis E., Ghirardi M., Posewitz M., Seibert M., Darzins A. 2008 - Microalgal triacylglycerols as feedstocks for biofuel production: perspectives and advances - Plant J. 54: 621-639.

Khatun B., Rahman R., Rahman M.S. 2014 - Evaluation of yeast Saccharomyces cerevisiae and algal Chlorella vulgaris as diet for rotifer Brachionus calyciflorus - The Agriculturists $12: 1-9$.

Khudyi O., Kolman R., Khuda L., Marchenko M., Terteryan L. 2014 - Characterization of growth and biochemical composition of sterlet, Acipenser ruthenus L., juveniles from the Dniester population reared in RAS - Arch. Pol. Fish. 22: 249-256.

Khudyi O., Marchenko M., Cheban L., Khuda L., Kushniryk O., Malishchuk I. 2016 - Recirculating aquaculture systems waste water as a medium for increase of phytoplankton and zooplankton biomass - Int. Lett. Nat. Sci. 54: 1-7.

Kim S.K., Wijesekara I. 2010 - Development and biological activities of marine-derived bioactive peptides: A review J. Funct. Foods. 2: 1-9.

Knight J.A., Anderson S., Rawle J.M. 1972 - Chemical basis of the sulfo-phospho-vanillin. Reaction for estimating total serum lipid - Clin. Chem. 18: 199-202.

Koller M., Muhr A., Braunegg G. 2014 - Microalgae as versatile cellular factories for valued products - Algal Res. 6: 52-63.

Kushniryk O., Khudyi O., Khuda L., Kolman R., Marchenko M. 2015 - Cultivating Moina macrocopa Straus in different media using carotenogenic yeast Rhodotorula - Arch. Pol. Fish. 23: 37-42.

Lavens P., Sorgeloos P. 1996 - Manual on the production and use of live food for aquaculture - FAO Fisheries Technical Paper No. 361, Rome.

Lowry O.H., Rosebrough N.J., Farr A.L., Randall R.J. 1951 Protein measurement with the Folin phenol reagent - J. Biol. Chem. 193: 265-275.

Macedo C.F., Pinto-Coelho R.M. 2001 - Nutrition status response of Daphnia laevis and Moina micrura from a tropical reservoir to different algal diets: Scenedesmus quadricauda and Ankistrodesmus glacilis - Braz. J. Biol. 61: 555-562.
Moyseev N.N. 2007 - Growing of live forages - Fish farming and fisheries, 12: 43-51 (in Russian).

Mulders K.J.M., Weesepoel Y., Lamers P.P., Vincken J.P., Martens D.E. Wijffels R.H. 2013 - Growth and pigment accumulation in nutrient-depleted Isochrysis aff. galbana T-ISO - J. Appl. Phycol. 25: 1421-1430.

Mychukova M.V., Kanarskyy A.V., Kanarskaya Z.A. 2007 Areas of using the culture of Daphnia magna Str. - Bulletin of the Kazan Technological University, 3-4: 109-126 (in Russian).

Nandini S., Sarma SSS. 2003 - Population growth pf some genera of cladocerans (Cladocera) in relation to algal food (Chlorella vulgaris) levels - Hydrobiologia 491: 211-219.

Ostroumova I.N. 2012 - Biological principles of fish feeding $\mathrm{SPb}$, State Research Institute of Lake and River Economy, 564 p. (in Russian).

Ricardi N., Mangoni M. 1999 - Considerations on the biochemical composition of some freshwater zooplankton species - J. Limnol. 58 : 58-65.

Roe S.H. 1955 - The determination of sugar in blood and spinal fluid with anthrone reagent - J. Biol. Chem. 212: 334-343.

Safafar H., van Wagenen J., Møller P., Jacobsen C. 2015 Carotenoids, phenolic compounds and tocopherols contribute to the antioxidative properties of some microalgae species grown on industrial wastewater - Mar. Drugs 13: 7339-7356.

Salama E.S., Kim H.C., Abou-Shanab R.I., Ji M.K., Oh Y.K., Kim S.H., Jeon B.H. 2013 - Biomass, lipid content, and fatty acid composition of freshwater Chlamydomonas mexicana and Scenedesmus obliquus grown under salt stress - Bioprocess Biosyst. Eng. 36: 827-833.

Samek D., Mišurcová L., Machů L., Buňka F., Fišera M. 2013 - Influencing of amino acid composition of green freshwater algae and cyanobacterium by methods of cultivation. - Turk. J Biochem. 38: 360-368.

Sánchez-Macías M.D., Serrano C.M., Rodríguez M.R., de la Ossa E.M., Lubían L.M., Montero O. 2008 - Extraction of carotenoids and chlorophyll from microalgae with supercritical carbon dioxide and ethanol as cosolvent - J. Sep. Sci. 31: 1352-1362.

Suantika G., Muhammad H., Azizah F.F.N., Rachminiwati N., Situmorang M.L., Astuti D.I., Aditiawati P. 2016 - The use of cyanobacteria Arthrospira platensis and cladoceran Daphnia magna as complementary protein and lipid sources in transitional diet for common carp (Cyprinus carpio L.) nursery - Nat. Res. 7: 423-433.

Tanaka Y. 1978 - Comparative biochemical studies on carotenoids in aquatic animals - Mem. Fac. Fish. Kagashima University, 27: 355-422.

Tuchapska A., Krazhan S. 2014 - Cultivation of cladoceran for increasing provision of young-of-the-year carp with natural feeds (Review) - Ribogospod. nauka Ukr. 28: 55-68 (in Ukrainian).

Villarruel-López A., Ascencio F., Nuńo K. 2017 - Microalgae, a Potential Natural Functional Food Source - a Review Pol. J. Food Nutr. Sci. 67: 251-263. 